A. S. FOUDA' ${ }^{1 *}$ M. MORSI ${ }^{2}$, H. A. MOSALLAM ${ }^{3}$

${ }^{1}$ El-Mansoura University, Department of Chemistry, Faculty of Science, El-Mansoura, Egypt, ${ }^{2}$ Tanta University, Department of Chemistry, Faculty of Science, Tanta, ${ }^{3}$ Water and waste water company, Dakahlia, Egypt
Scientific paper

ISSN 0351-9465, E-ISSN 2466-2585

UDC:620.193.4:669.11

doi:10.5937/ZasMat1601033F

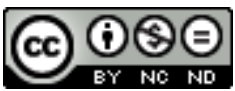

Zastita Materijala 57 (1)

$33-45$ (2016)

\title{
Capsicum extract as green corrosion extract for carbon steel in hydrochloric acid solutions
}

\begin{abstract}
The extract of Capsicum have been evaluated as green extract for the corrosion of carbon steel in $1 \mathrm{M} \mathrm{HCl}$ solution was investigated using weight loss, potentiodynamic polarization, ac electrochemical impedance spectroscopy (EIS), electrochemical frequency modulation (FEM) and energy dispersion spectroscopy (EDS) and scanning electron microscopy (SEM) methods of monitoring corrosion. The inhibitive property of the extract is attributed to the presence of Capsaicin and Ascorbic acid as major constituent in the extract. Measurements showed that this extract act as mixed-type extract. The inhibition efficiency was found to increase with extract concentration. Results obtained by various techniques are close to each other and maximum efficiency of $86 \%$ is acknowledged at the extract concentration of 300 ppm. Langmuir isotherm model is found most suitable to explain adsorption behavior of extract for $C$-steel surface. Molecular adsorption of extract over $C$ - steel surface is found responsible for corrosion inhibition of C- steel in acid.
\end{abstract}

Keywords: Corrosion inhibition, Capsicum extract, C- steel, $\mathrm{HCl}$.

\section{INTRODUCTION}

Corrosion extracts are chemical compounds usually used in small concentrations whenever a metal is in contact with an aggressive medium. The presence of such compounds retards the corrosion process and keeps its rate to a minimum and thus prevents economic losses due to metallic corrosion. The chemical compounds that could be used for this purpose may be organic or inorganic. However, not just any chemical compound can be used as a corrosion extract. There are some requirements that the compound must fulfill to do so. Regarding the chemical structure and chemical behavior, an inorganic compound must be able to oxidize the metal, forming a passive layer on its surface. On the other hand, a molecule of an organic compound must have some features that give it the ability to act as a corrosion extract. Among these, the molecule may have a large structure, double bonds, an active center or group, etc.

${ }^{*}$ Corresponding author: A. S. Fouda

Email: asfouda@mans.edu.eg

Paper received: 06. 08. 2015

Paper accepted: 30. 09. 2015.

Paper is available on the website: www.idk.org.rs/casopis
These features give the molecule the ability to cover a large area of a metal surface with a firmly attached film [1].

Apart from the structural aspects, there are also economic and environmental considerations. Thus, since the whole subject of corrosion is about its destructive economical effect, the used extract must be cheap. Furthermore, due to the recent increasing awareness of green chemistry, it must be a nontoxic and environmentally friendly chemical. One of the sources of these cheap and clean extracts is plants. Plant parts contain several compounds that satisfy the mentioned criteria. Many recent researches [2-9] have adopted this trend and carried out their work on naturally occurring substances. Promising results were obtained in previous work in this field. It was reported that Khillah extract inhibits steel corrosion in $\mathrm{HCl}$ solution with inhibition efficiency as high as 99\% [2], while opuntia extract inhibits the corrosion of aluminum in the same acid with efficiency of about $96 \%$ [9].

The aim of this work is to study the effect of using extract of Capsicum as green extract for the corrosion of $\mathrm{C}$ - steel in $1 \mathrm{M} \mathrm{HCl}$ using weight loss method (chemical method)and the electrochemical techniques (potentiodynamic polarization measurements, electrochemical impedance spectroscopy (EIS) techniques and electrochemical frequency modulation method) 


\section{EXPERIMENTAL}

\subsection{Materials}

The experiments were performed with C- steel specimens in the form of rods and sheets with the following composition (weight \%):0.200 C, 0.350 $\mathrm{Mn}, 0.024 \mathrm{P}, 0.003 \mathrm{~S}$, and the remainder Fe. For electrochemical measurements, the sheets were welded with $\mathrm{Cu}$-wire for electrical connection and mounted into glass tubes of appropriate diameter using Araldite to offer an active surface of $1 \mathrm{~cm}^{2}$ geometric area, to contact the test solution. Prior to each experiment, these sheets were polished with emery paper (400-1200 grit size) to a mirror finish and degreased with trichloroethylene, washed with bidistilled water and then dried. A conventional electrochemical cell of capacity $100 \mathrm{ml}$ was used containing three compartments for C- steel as working electrode, platinum foil with a $1 \mathrm{~cm}^{2}$ surface area was chosen as the counter electrode and saturated calomel electrode (SCE) via a Luggin capillary probe was used as the reference. All reagents used $(\mathrm{HCl})$ for this study was of analytical grade and were used as received and bidistilled water was used for their preparations. All experiments were carried out open to the atmosphere. The experiments were repeated and reproducibility was tested and confirmed.

\subsection{Test solution}

Capsicum is very popular in world and used as vegetable in many regions. The extract of this plant contains many organic compounds as flavonoids, ascorbic acid, phenolic acids, polysaccharide and capsaicin [10-12]. This plant is selected for the study due to simple extraction method, non toxic nature, low cast and presence of effective organic compounds which contain $\mathrm{N}, \mathrm{O}$ heteroatoms, $-\mathrm{OH}$ group and $\pi$ electrons in their structures (fig.1). Although crude extract is used in this study for simplicity and effective cost but we are working on purification of the extract to enhance the inhibition efficiency at low concentration. Fresh fruits were bought from the local market and washed with bidistilled water. Fruits were cut and dried at $40^{\circ} \mathrm{C}$ for two days. Powdered form of fruits was obtained using grinder and bidistilled water was added to make a solution. This solution was kept at room temperature for two days with constant stirring. Further extract was filtered and water was evaporated using rotatory evaporator. Solid residue obtained by this process was again dissolved in $100 \mathrm{~mL}$ bidistilled water and stock solution was prepared.

\begin{tabular}{|c|c|c|c|}
\hline Chemical Constituents & IUPAC names \\
\hline Ascorbic acid & Capsaicin & Methyl-N-vanillyl-trans-6-nonenamide \\
\hline
\end{tabular}

Figure 1 - Molecular structures and names of main components in Capsicum extract

\subsection{Methods}

\subsubsection{Weight loss Measurements}

The samples measuring $2 \times 2 \times 0.2 \mathrm{~cm}$ were prepared as before. The specimens were immersed in $250 \mathrm{ml}$ beaker, which contained $100 \mathrm{ml}$ of $1 \mathrm{M} \mathrm{HCl}$ with and without different concentrations of extract. After $3 \mathrm{~h}$, the specimens were taken out, washed, dried, and weighed accurately. The average weight loss of the parallel C-steel sheets could be obtained. Then the tests were carried out at a temperature range $25-55^{\circ} \mathrm{C}$. The inhibition efficiency (IE), surface coverage $(\Theta)$ of the extract and corrosion rate (CR) in $\mathrm{mg} \mathrm{cm}^{-2} \mathrm{~min}^{-1}$ of $\mathrm{C}$-steel in $\mathrm{HCl}$ solution were calculated using equations 1 and 2 , respectively [13]:

$$
\begin{aligned}
& \% I E=\Theta \times 100=\left[1-\left(W_{1} / W_{2}\right)\right] \\
& C R=\left[W_{2}-W_{1}\right] / A t
\end{aligned}
$$

where $W_{1}$ and $W_{2}$ are the weight losses $\left(\mathrm{mg} \mathrm{cm}^{-2}\right)$ in the presence and absence of the extract, respectively, $A$ is the area of the specimen in $\mathrm{cm}^{-2}$ and $t$ is the period of immersion in min.

\subsubsection{Electrochemical Measurements}

\subsubsection{Potentiodynamic polarization measurements}

Before polarization scanning, working electrode was immersed in the test solution $(100 \mathrm{ml})$ for 30 min until steady state was attained this was taking as open circuit potential, EOCP. All experiments 
were carried out at $25 \pm 1 \stackrel{\circ}{\circ} \mathrm{C}$ and solutions were not aerated. For polarization measurements potential from -300 to $100 \mathrm{mV}$ [relative to $E_{O C P}$ ] was applied. The inhibition efficiency and surface coverage $(\Theta)$ were calculated using equation (3):

$$
\% \operatorname{IE}=\left[1-\left(i_{\text {corr(inh) }} / i_{\text {corr(free })}\right)\right] \times 100
$$

where $i_{\text {corr(free) }}$ and $i_{\text {corr(inh) }}$ are the corrosion current densities in the absence and presence of extract, respectively.

\subsubsection{Electrochemical impedance spectroscopy}

(EIS) method

The EIS spectra were recorded at OCP after immersion of the electrode for $30 \mathrm{~min}$ in the test solution in order to attain steady state. The AC signal was $5 \mathrm{mV}$ peak to peak and the frequency range studied was between $100 \mathrm{kHz}$ and $0.2 \mathrm{~Hz}$.

The $\%$ IE and the surface coverage $(\theta)$ of the used extracts obtained from the impedance measurements can be calculated using equation (4):

$$
\% I E=\theta \times 100=\left[1-\left(R_{c t}^{\circ} / R_{C t}\right)\right] \times 100
$$

$\mathrm{R}_{\mathrm{ct}}^{\circ}$ and $\mathrm{R}_{\mathrm{ct}}$ are the charge transfer resistance in the absence and presence of extract, respectively

\subsubsection{Electrochemical frequency modulation} (EFM) method

Electrochemical frequency modulation (EFM) was carried out using two frequencies 2 and $5 \mathrm{~Hz}$. The base frequency was $0.1 \mathrm{~Hz}$, so the waveform repeats after 1s. The Intermodulation spectra contain current responses assigned for harmonical and intermodulation current peaks. The larger peaks were used to calculate the corrosion current density $\left(i_{\text {corr }}\right)$, the Tafel slopes $\left(\beta_{c}\right.$ and $\left.\beta_{a}\right)$ and the causality factors CF-2\& CF-3 $[14,15]$.

All electrochemical experiments were carried out using Potentiostat/Galvanostat/Zra analyzer (Gamry PCI300/4). A personal computer with DC 105 software for polarization, EIS 300 software for impedance, EFM140 software for electrochemical frequency modulation and Echem Analyst 5.21 was used for data fitting and calculating.

\section{RESULTS AND DISCUSSION}

\subsection{Weight loss method}

The weight loss-time curves of C-steel specimens in $1 \mathrm{M} \mathrm{HCl}$ solution, with and without different concentrations from the investigated Capsicum extract, was determined after $3 \mathrm{~h}$ of immersion at $25^{\circ} \mathrm{C}$ are given in Figure $2 . \% \mathrm{IE}$ are given in Table 1.

Table 1 - Data of weight loss measurements for $C$-steel in $1 \mathrm{M} \mathrm{HCl} \mathrm{solution} \mathrm{in} \mathrm{the} \mathrm{absence} \mathrm{and} \mathrm{presence}$

\begin{tabular}{|c|c|c|c|c|}
\hline Temperature, ${ }^{\circ} \mathrm{C}$ & Conc., ppm & Weight loss, $\mathrm{mg} \mathrm{cm}^{-2}$ & $\theta$ & $\%$ IE \\
\hline \multirow{7}{*}{25} & Blank & 6.50 & -- & -- \\
\hline & 50 & 1.96 & 0.698 & 69.8 \\
\hline & 100 & 1.83 & 0.718 & 71.8 \\
\hline & 150 & 1.78 & 0.726 & 72.6 \\
\hline & 200 & 1.58 & 0.757 & 75.7 \\
\hline & 250 & 1.09 & 0.832 & 83.2 \\
\hline & 300 & 0.89 & 0.863 & 86.3 \\
\hline \multirow{7}{*}{35} & Blank & 11.16 & -- & -- \\
\hline & 50 & 3.65 & 0.668 & 66.8 \\
\hline & 100 & 3.41 & 0.691 & 69.1 \\
\hline & 150 & 3.18 & 0.711 & 71.1 \\
\hline & 200 & 2.99 & 0.727 & 72.7 \\
\hline & 250 & 2.71 & 0.746 & 74.6 \\
\hline & 300 & 2.63 & 0.761 & 76.1 \\
\hline \multirow{7}{*}{45} & Blank & 28.45 & -- & -- \\
\hline & 50 & 10.94 & 0.616 & 61.6 \\
\hline & 100 & 9.83 & 0.655 & 65.5 \\
\hline & 150 & 8.92 & 0.687 & 68.7 \\
\hline & 200 & 8.28 & 0.709 & 70.9 \\
\hline & 250 & 7.97 & 0.721 & 72.1 \\
\hline & 300 & 7.56 & 0.735 & 73.5 \\
\hline \multirow{7}{*}{55} & Blank & 57.34 & -- & -- \\
\hline & 50 & 25.27 & 0.559 & 55.9 \\
\hline & 100 & 23.00 & 0.599 & 59.9 \\
\hline & 150 & 22.30 & 0.611 & 61.1 \\
\hline & 200 & 20.50 & 0.642 & 64.2 \\
\hline & 250 & 19.40 & 0.661 & 66.1 \\
\hline & 300 & 18.30 & 0.681 & 68.1 \\
\hline
\end{tabular}
of different concentrations of Capsicum extract at temperature ranges $\left(25-55^{\circ} \mathrm{C}\right)$ 
The presence of Capsicum extract reduces the corrosion rate of $\mathrm{C}$-steel in $\mathrm{HCl}$. From the plot, weight loss for systems containing Capsicum extract was found to be lower compared to the blank indicating that different concentrations of Capsicum extract retards the corrosion of $\mathrm{C}$-steel in $1 \mathrm{M} \mathrm{HCl}$. The Figure reveals that the Capsicum extract actually inhibited the $\mathrm{HCl}$ induced corrosion of C-steel to an appreciable extent. The Figure also reveals that $\mathrm{C}$-steel corrosion by $\mathrm{HCl}$ occurs not by simple homogenous process but by a heterogeneous one consisting of different or same rates. This assertion is made from the nonuniformity or nonlinearity of the plots obtained [16].

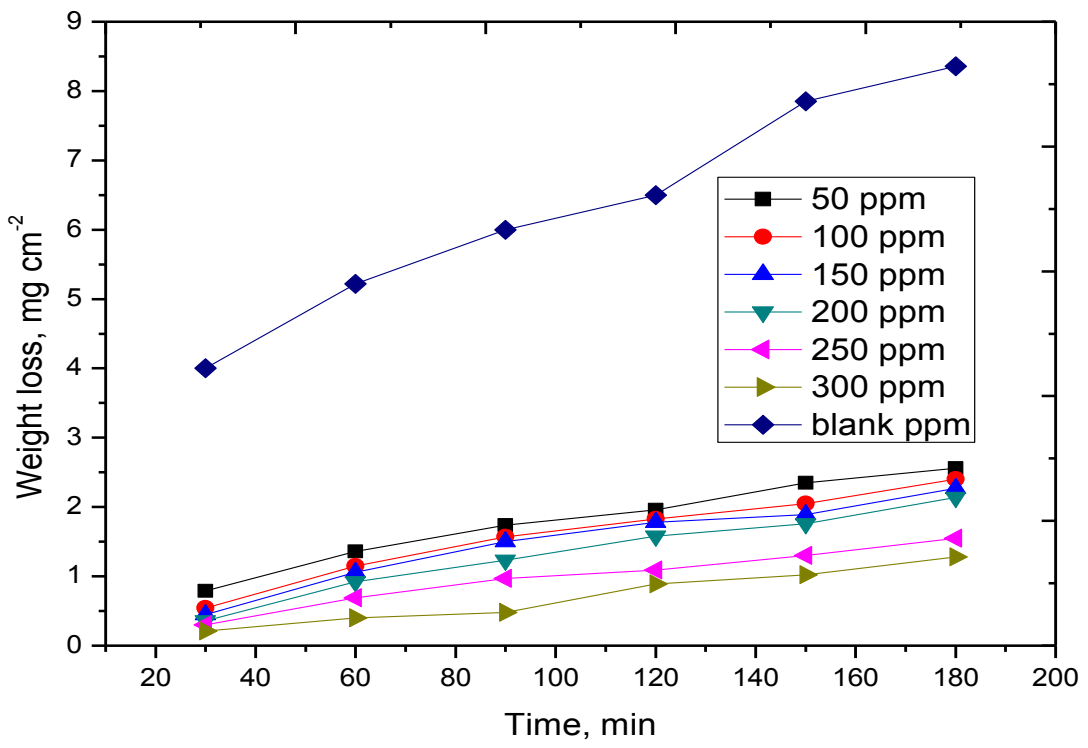

Figure 2 - Weight loss-time curves for the corrosion of $C$-steel in $1 \mathrm{M} \mathrm{HCl}$ in absence and presence of different concentrations of Capsicum extract at $25^{\circ} \mathrm{C}$

\subsection{Adsorption isotherms and thermodynamics parameters}

The mechanism of the interaction between extract and the metal surface can be explained using adsorption isotherms The degree of surface coverage, $\theta$, was computed for the different concentrations of the extract from weight loss measurements as follows: $\% \mathrm{IE}=\theta \times 100$, assuming direct relationship between surface coverage and inhibition efficiency. The surface coverage values obtained were applied to various adsorption isotherm models. By far, the best fit was found to obey Langmuir adsorption isotherm (Figure 3 ), which may be formulated as in equation (5):

$$
C / \theta=1 / K_{a d s}+C
$$

where $\mathrm{K}_{\mathrm{ads}}$ is the adsorption equilibrium constant of the extract and $C$ is the extract concentration. The free energy of adsorption ( $\Delta \mathrm{G}_{\circ \text { ads }}$ ) can be obtained from equation (6):

$$
\log K_{a d s}=-\log 55.5-\Delta G_{\text {ads }} / 2.303 R T
$$

where $R$ is the universal gas constant, $T$ is the absolute temperature, The value 55.5 is the concentration of water on the metal surface in $\mathrm{mol} /$ $\mathrm{L}$. The negative values of $\Delta \mathrm{G}_{\text {ads }}^{\circ}$ in Table (2) suggested that the adsorption of extract molecules onto $\mathrm{C}$-steel surface is a spontaneous process. Generally, values of $\Delta \mathrm{G}^{\circ}$ ads up to $-20 \mathrm{~kJ} \mathrm{~mol}^{-1}$ are consistent with the electrostatic interaction between the charged molecules and the charged metal (physical adsorption) while those more negative than $-40 \mathrm{~kJ} \mathrm{~mol}^{-1}$ involve charge sharing or transfer of electrons from the extract molecules to the metal surface to form a co-ordinate type of bond (chemisorption) $[17,18]$. The large $\mathrm{K}_{\mathrm{ads}}$ values give better inhibition efficiency due to strong electrical interaction between the double layer and adsorbing extract molecules while a small $\mathrm{K}_{\mathrm{ads}}$ values compromise that such interactions between the adsorbing extract molecules and the metal surface are weaker, indicating that the extract molecules are easily removable by the solvent molecules from the surface of C-steel. Figure (4) shows the plot of $\log \mathrm{K}_{\mathrm{ads}}$ vs. 1/ $\mathrm{T}$, a straight line with an intercept equal to $\Delta \mathrm{H}^{\circ}$ ads and with slope equal to $\Delta \mathrm{S}^{\circ}$ ads were obtained as in Equation (7):

$$
\Delta G^{\circ}{ }_{a d s}=\Delta H^{\circ}{ }_{a d s}-T \Delta S^{\circ}{ }_{a d s}
$$

The negative sign of $\Delta \mathrm{H}^{\circ}$ ads indicated that the adsorption of extract molecules is an exothermic process in all cases. The sign of $\Delta \mathrm{S}^{\circ}$ ads is negative because extract molecules freely moving in the bulk solution were adsorbed in an orderly fashion on to C-steel, resulting in a decrease in entropy [19]. Moreover, from thermodynamic principles, since the adsorption was an exothermic process, it must be accompanied by a decrease in entropy [20]. 


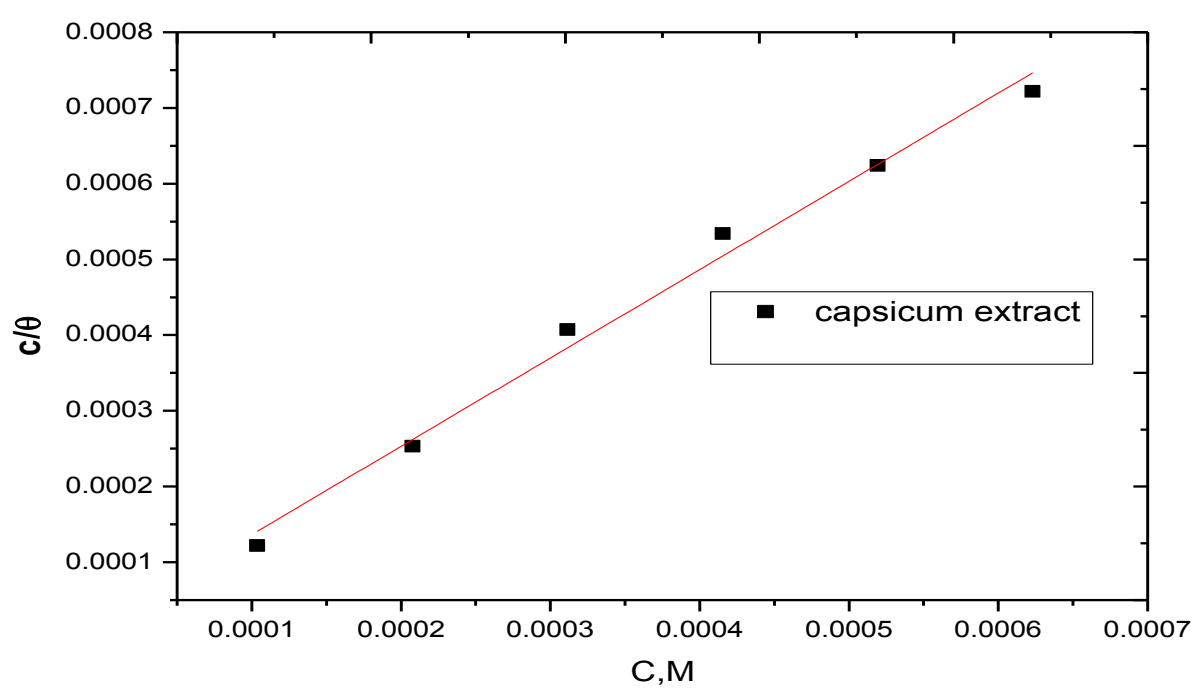

Figure 3 - Adsorption isotherm for the adsorption of extract on $\mathrm{C}$-steel in $1 \mathrm{M} \mathrm{HCl}$ at $25^{\circ} \mathrm{C}$

Table 2 - Thermodynamic parameters for $C$-steel in $1 \mathrm{M} \mathrm{HCl}$ for Capsicum extract

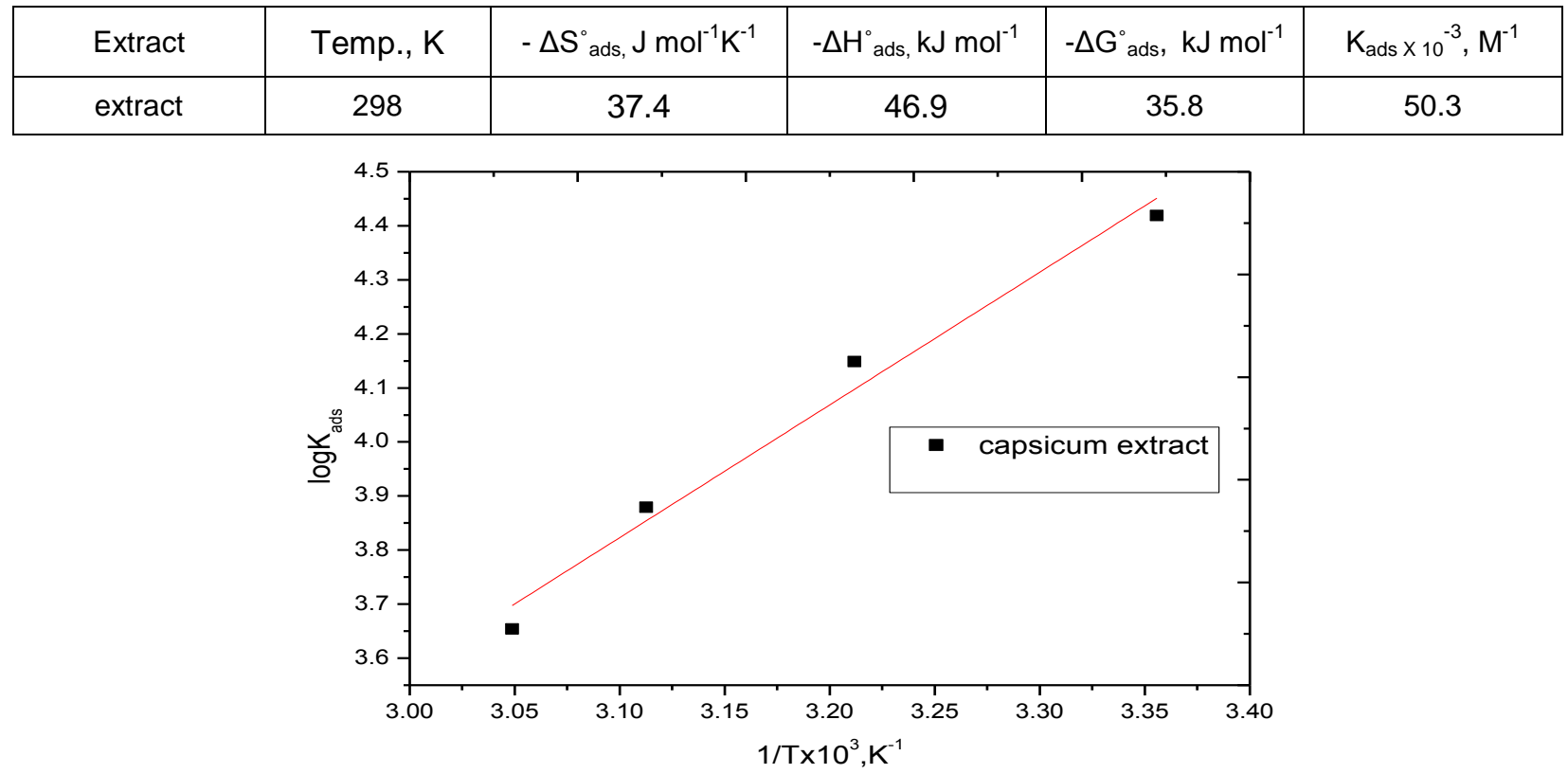

Figure 4 - Variation of $\log K_{\text {ads }}$ with $1 / T$

\subsection{Effect of temperature}

Temperature plays an important role on metal dissolution. The corrosion rate in acid solution, for example, increases exponentially with temperature increase because the hydrogen evolution overpotentials increases [21]. In order to access the effect of temperature on the corrosion and corrosion inhibition process, weight loss experiments were carried out in the temperature range $25-55^{\circ} \mathrm{C}$ in $1 \mathrm{M} \mathrm{HCl}$ in the absence and presence of different concentrations (50-300 ppm) of Capsicum extract. It was found that after $3 \mathrm{~h}$ immersion period, the surface coverage and inhibition efficiency decrease with rise in temperature (Table 1). Arrhenius-type dependence is observed between corrosion rate and temperature often expressed as in equation (8):

$$
\text { Corrosion Rate }(C R)=A \text { exp }-E_{a}^{*} / R T
$$

where $C R$ is the corrosion rate, $E^{*}{ }_{a}$ is the apparent activation energy and $A$ is the frequency factor. Figure 5 depicts an Arrhenius plot (logarithm of CR against the reciprocal of temperature $(1 / \mathrm{T})$ for $\mathrm{C}$ steel in $1 \mathrm{M} \mathrm{HCl}$ solution in the absence and presence of different extract concentrations. Satisfactory straight lines of high correlation coefficients were obtained. The values of activation energy were obtained from the slopes of the linear plots and are given in Table 3 . It is clear that $\mathrm{E}_{\mathrm{a}}{ }^{*}$ values in the presence of the different concentrations of the extract are higher than in their absence. 
Table 3 - Kinetic activation parameters for $C$-steel in $1 \mathrm{M} \mathrm{HCl}$ in the absence and presence $150 \mathrm{ppm}$ Capsicum extract

\begin{tabular}{|c|c|c|c|c|}
\hline \multirow[b]{2}{*}{ Extracts } & \multirow[b]{2}{*}{$\begin{array}{l}\text { Conc. } \\
\text { ppm }\end{array}$} & \multicolumn{3}{|c|}{ Activation parameters } \\
\hline & & $\begin{array}{c}\mathrm{E}_{\mathrm{a}}{ }^{*}, \\
\mathrm{~kJ} \mathrm{~mol}^{-1}\end{array}$ & $\begin{array}{c}\Delta \mathbf{H}^{*}, \\
\mathbf{k J ~ m o l}^{-1}\end{array}$ & $\begin{array}{c}-\Delta \mathbf{S}^{*} \\
\mathrm{~J} \mathrm{~mol}^{-1} \mathrm{~K}^{-1}\end{array}$ \\
\hline Blank & 0.0 & 42.0 & 21.0 & 155.3 \\
\hline Extract & 150 & 74.5 & 55.1 & 97.1 \\
\hline
\end{tabular}

The higher in apparent activation energy in the presence of the extract denotes physical adsorption while the reverse is usually attributed to chemical adsorption [22]. This conclusion is denoted by the decrease in inhibition efficiency with increasing temperature (Table 1). Similar result has been reported by Okafor et al. [23] on the inhibition of acid corrosion of carbon steel using aqueous extract of P. amarus seeds and leaves. Moreover, the increase in activation energy is proportional to the extract concentration, indicating that the energy barrier for the corrosion process is also increased
[24]. An alternative formulation of Arrhenius equation is [25]:

$$
C R=(R T / N h) \exp \left(\Delta S^{*} / R\right) \exp \left(-\Delta H^{*} / R T\right)
$$

where $h$ is the Planck's constant and $N$ is the Avogadro's number, $\Delta S^{*}$ is the entropy of activation, and $\Delta \mathrm{H}^{*}$ is the enthalpy of activation. Figure 6 shows a plot of $\log (\mathrm{CR} / \mathrm{T})$ as a function of $1 / \mathrm{T}$. Straight lines were obtained with a slope of $\left(\Delta \mathrm{H}^{*} /\right.$ $\mathrm{R})$ and an intercept of ( $\left.\mathrm{InR} / \mathrm{Nh}-\Delta \mathrm{S}^{*} / \mathrm{R}\right)$ from which the values of $\Delta \mathrm{H}^{*}$ and $\Delta \mathrm{S}^{*}$ were calculated Table 3.

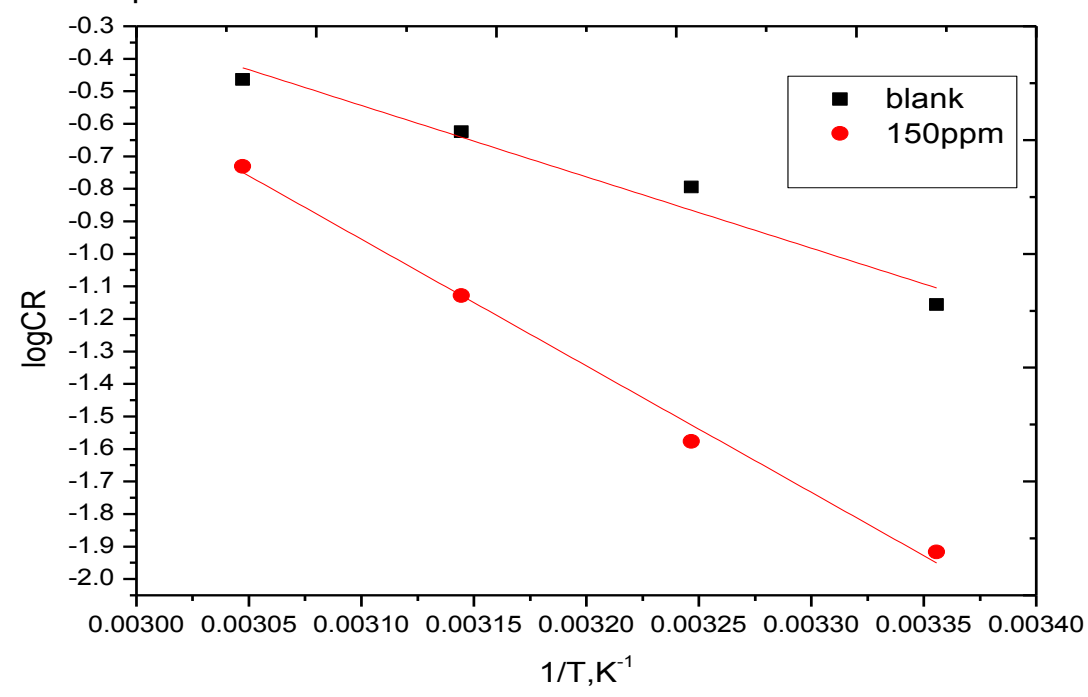

Figure 5 - Arrhenius plot of variation of $(\log C R)$ vs. $1 / T)$ for dissolution of $C$-steel in $1 \mathrm{M} \mathrm{HCl}$ in absence and presence of $150 \mathrm{ppm}$ of Capsicum extract

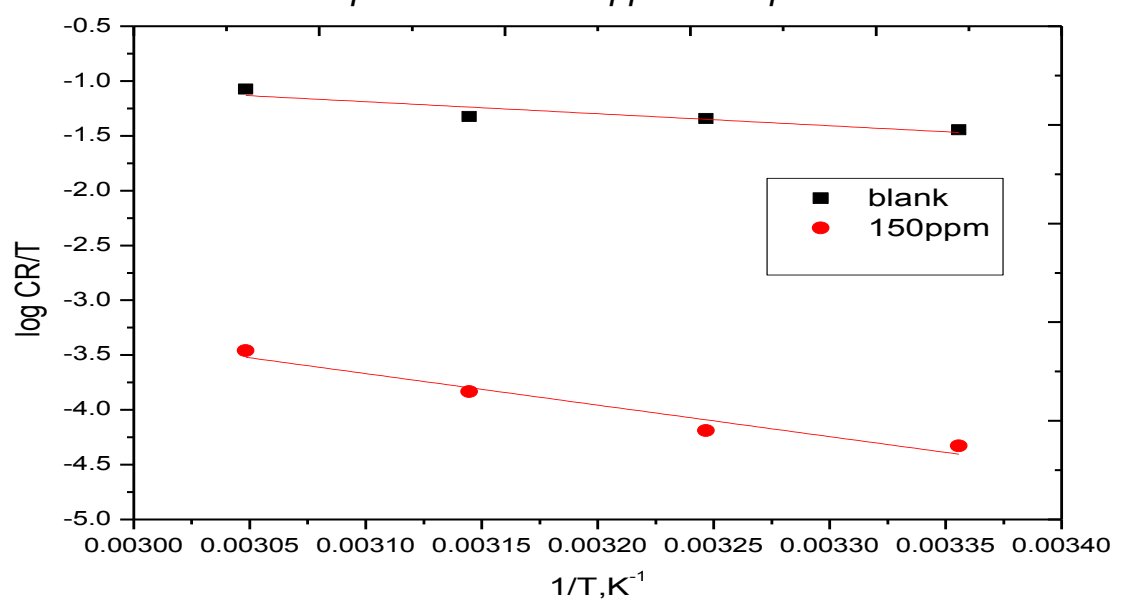

Figure 6 - Arrhenius plot of variation of (log CR/T) vs. 1/T) for dissolution of $C$-steel in $1 M \mathrm{HCl}$ in in absence and presence of 150 ppm of Capsicum extract 
The positive values of $\Delta \mathrm{H}^{*}$ both in the absence and presence of the extract reflect the endothermic nature of the C-steel dissolution process. It is also clear that the activation enthalpies vary in the same manner as the activation energies, supporting the proposed inhibition mechanism. Large and negative values of entropies imply that the activated complex in the rate determining step represents an association rather than a dissociation step, meaning that a decrease in disordering takes place on going from reactants to the activated complex. Similar observation has been reported in the literature [25].

\subsection{Potentiodynamic polarization measurements}

Potentiodynamic polarization curves for $\mathrm{C}$-steel in uninhibited and inhibited acidic solutions containing different concentrations of Capsicum extract are shown in Figure 7. The corrosion kinetic parameters derived from potentiodynamic polarization curves together with \% IE are listed in
Table 4. It has been observed that values of corrosion current density ( $\left.\mathrm{i}_{\text {corr }}\right)$ for $\mathrm{C}$-steel in $1 \mathrm{M}$ $\mathrm{HCl}$ solution decreased with increase in Capsicum extract concentration. The decrease in corrosion current densities in the presence of extract might be due to the adsorption of Capsicum extract components molecules on the C-steel surface. In the absence and presence of Capsicum extract, $\beta_{a}$ and $\beta_{c}$ values remain more or less identical indication that the effect of extract is not as large as to change the mechanism of corrosion. The value of corrosion potential $\left(E_{\text {corr. }}\right)$ showed a slight shift towards anodic region as concentration of extract increased, suggesting the effect of extract is more pronounced at anodic site. It was reported before [26] that, if the displacement in corrosion potential is more than $85 \mathrm{mV}$ with respect to corrosion potential of uninhibited solution, the extract can be seen as a cathodic or anodic type. In our study the maximum displacement was $15 \mathrm{mV}$, indicating that Capsicum extract belonged to mixed-type.

Table 4 - Corrosion parameters obtained from potentiodynamic polarization of C-steel in $1 \mathrm{M} \mathrm{HCl}$ containing various concentrations of Capsicum extract at $25^{\circ} \mathrm{C}$

\begin{tabular}{|c|c|c|c|c|c|c|c|c|}
\hline Comp. & $\begin{array}{c}\text { Conc., } \\
\mathrm{ppm}\end{array}$ & $\begin{array}{c}-\mathrm{E}_{\text {corr, }} \\
\mathrm{mVvs.SCE}\end{array}$ & $\begin{array}{c}\mathrm{i}_{\text {corr }} \\
\mathrm{mA} \mathrm{cm}\end{array}$ & $\begin{array}{c}\beta_{\mathrm{c}} \\
\mathrm{mV} \mathrm{dec}^{-1}\end{array}$ & $\begin{array}{c}\beta_{\mathrm{a}} \\
\mathrm{mV} \mathrm{dec}^{-1}\end{array}$ & $\theta$ & $\%$ IE & $\begin{array}{c}\text { CR } \\
\mathrm{mpy}\end{array}$ \\
\hline Blank & 0.0 & 449 & 959.0 & 236 & 160 & --- & -- & 252.9 \\
\hline \multirow{5}{*}{ Extract } & 50 & 462 & 230.4 & 161 & 97 & 0.760 & 76.0 & 104.9 \\
\cline { 2 - 10 } & 100 & 481 & 197.1 & 156 & 100 & 0.795 & 79.5 & 90.1 \\
\cline { 2 - 10 } & 150 & 471 & 190.8 & 172 & 99 & 0.802 & 80.2 & 86.9 \\
\cline { 2 - 10 } & 200 & 484 & 178.2 & 168 & 110 & 0.814 & 81.4 & 80.5 \\
\cline { 2 - 10 } & 250 & 485 & 161.60 & 119 & 138 & 0.832 & 83.2 & 76.9 \\
\hline
\end{tabular}

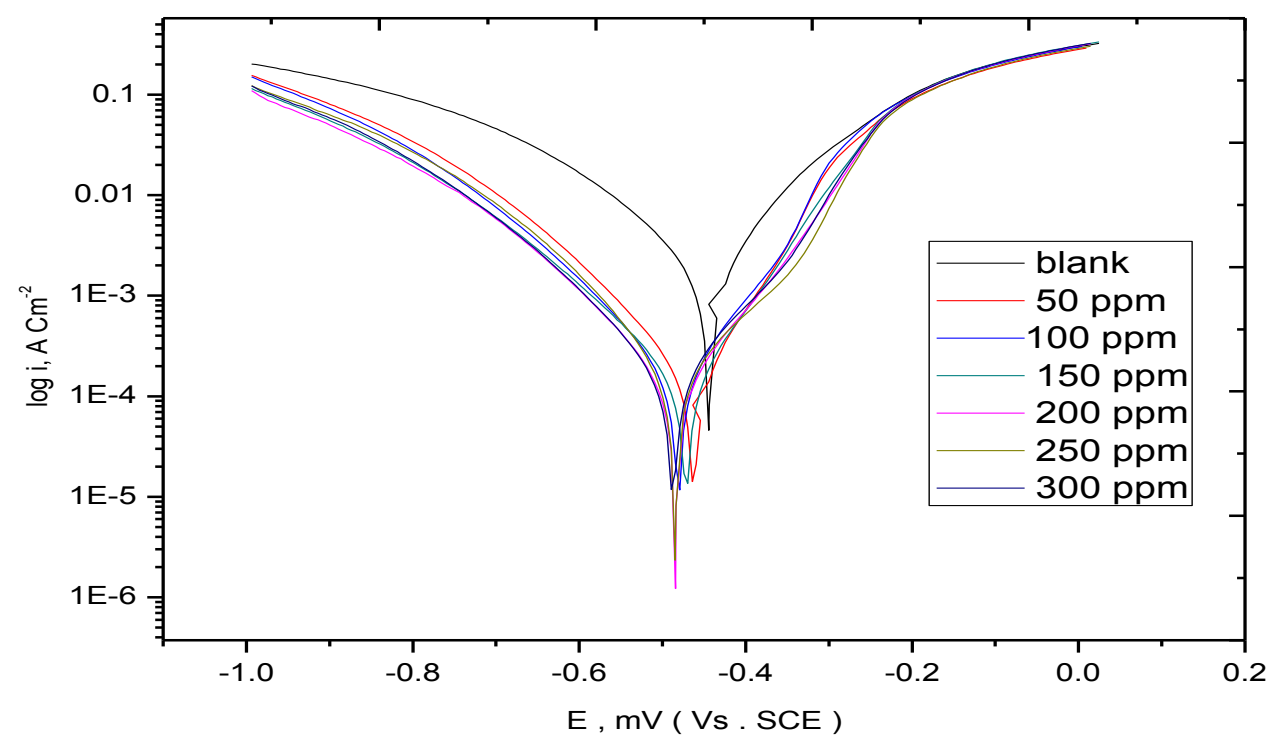

Figure 7 - Potentiodynamic polarization curves of $C$-steel in $1 \mathrm{M} \mathrm{HCl}$ in the absence and presence of different concentrations of Capsicum extract at $25^{\circ} \mathrm{C}$ 


\subsection{Electrochemical impedance spectroscopy} (EIS) method

The corrosion of $\mathrm{C}$-steel in $1 \mathrm{M} \mathrm{HCl}$ in the presence of Capsicum extract was investigated by EIS method at $25^{\circ} \mathrm{C}$. Impedance parameters, such as, charge transfer resistance $R_{c t}$, which is equivalent to $R_{p}$, and the double layer capacitance $C_{d l}$ are derived from the Nyquist plot (Figure 8 ) and are given in Table 5 for $\mathrm{C}$-steel in $1 \mathrm{M} \mathrm{HCl}$ acid solution in the presence and absence of the extract.

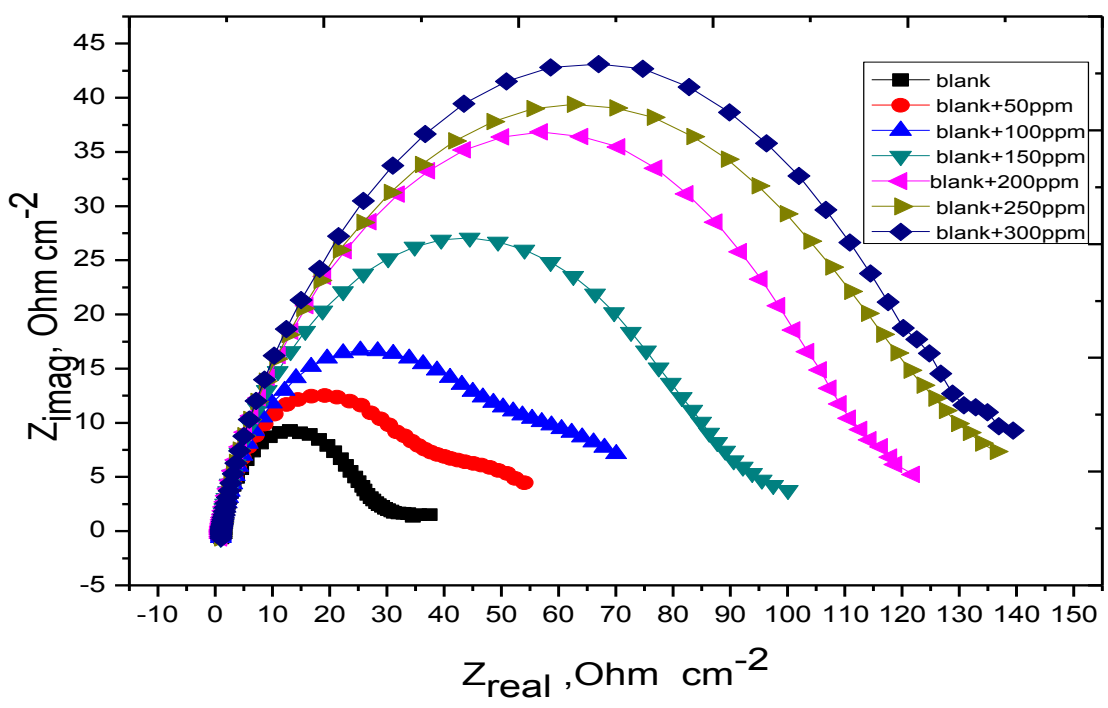

Figure 8 - Nyquist plot of $C$-steel in $1 \mathrm{M} \mathrm{HCl}$ in the absence and presence of different concentrations of Capsicum extract at $25^{\circ} \mathrm{C}$

It is observed that the values of $R_{c t}$ increase with increasing the concentration of the extract and this in turn leads to a decrease in corrosion rate of $\mathrm{C}$-steel in $1 \mathrm{M} \mathrm{HCl}$ acid solution. Impedance diagram have a semicircular appearance; the diagram indicate that the corrosion of C-steel is mainly controlled by a charge transfer process [27]. The values of double layer capacitance, $C_{d l}$, decrease with increasing the concentration of Capsicum extract. A low capacitance may result if water molecules at the electrode interface are replaced by extract molecules of lower dielectric constant through adsorption.

Table 5 - EIS data of $C$-steel in $1 \mathrm{M} \mathrm{HCl}$ and in the presence and absence of different concentrations of Capsicum extract at $25^{\circ} \mathrm{C}$

\begin{tabular}{|c|c|c|c|c|c|c|}
\hline Comp. & Conc., ppm & $\mathrm{C}_{\mathrm{dl}}, \mu \mathrm{F} \mathrm{cm}^{-2}$ & $\mathrm{n}$ & $\mathrm{R}_{\mathrm{ct}}, \Omega \mathrm{cm}^{2}$ & $\theta$ & $\% \mathrm{IE}_{\mathrm{EIS}}$ \\
\hline Blank & 0.0 & 132.0 & 0.834 & 28.5 & --- & --- \\
\hline \multirow{6}{*}{ 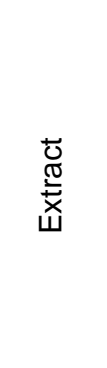 } & 50 & 110.4 & 0.862 & 41.4 & 0.311 & 31.1 \\
\hline & 100 & 98.5 & 0.853 & 57.3 & 0.500 & 50.0 \\
\hline & 150 & 84.1 & 0.814 & 85.5 & 0.667 & 66.7 \\
\hline & 200 & 75.7 & 0.846 & 109.9 & 741.0 & 74.1 \\
\hline & 250 & 70.4 & 0.881 & 125.6 & 0.766 & 76.6 \\
\hline & 300 & 64.2 & 0.873 & 149.1 & 0.810 & 81.0 \\
\hline
\end{tabular}

When such low capacitance values in connection with high $R_{c t}$ values, it is apparent that a relationship exists between adsorption and inhibition. The impedance data of $\mathrm{C}$-steel in $1 \mathrm{M} \mathrm{HCl}$ are analyzed in terms of an equivalent circuit model (Figure 9 ) which includes the double layer capacitance $C_{d l}$ which is placed in parallel to the charge transfer resistance $R_{c t}[28]$ due to the charge transfer reaction. $C_{d l}$ can be calculated from the angular frequency $(\omega=2 \pi \mathrm{f})$ at the maximum imaginary component and the charge transfer resistance according equation 9:

$$
C_{d l}=\left[1 / \omega_{\max } R_{p}\right]=\left[1 / 2 \pi f_{\max } R_{p}\right]
$$

where $f$ is maximum frequency, $\omega$ is the angular velocity 


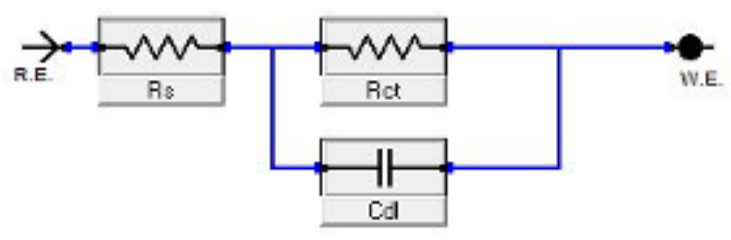

Figure 9 - Equivalent circuit model used to fit impedance data

\subsection{Electrochemical frequency modulation (EFM) method}

The EFM is a nondestructive corrosion measurement technique that can directly give values of the corrosion current without prior knowledge of Tafel constants. Like EIS, it is a small ac signal. Intermodulation spectra obtained from EFM measurements are presented in Figures (10 and 11) as examples of $\mathrm{C}$-steel in aerated $1 \mathrm{M} \mathrm{HCl}$ solutions devoid of and containing different concentrations of Capsicum extract at $25^{\circ} \mathrm{C}$. Each spectrum is a current response as a function of frequency. The calculated corrosion kinetic parameters at different concentrations of Capsicum extract in $1 \mathrm{M} \mathrm{HCl}$ at $25^{\circ} \mathrm{C}\left(\mathrm{i}_{\text {corr }}, \beta_{\mathrm{a}}, \beta_{\mathrm{c}}, \mathrm{CF}-2, \mathrm{CF}-3\right.$ and $\%$ IE) are given in Table (6). From Table 6, the corrosion current densities decrease by increasing the concentration of Capsicum extract and the inhibition efficiency increases by increasing the extract concentration.

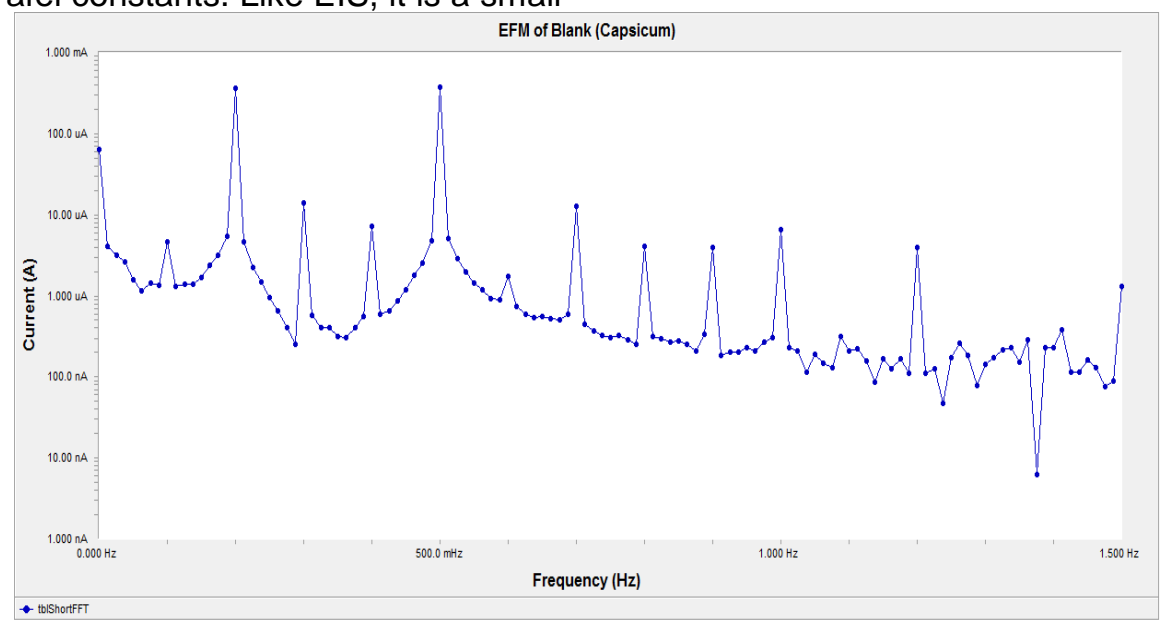

Figure 10 - EFM spectra for $\mathrm{C}$-steel in $1 \mathrm{M} \mathrm{HCl}$ (blank) at $25^{\circ} \mathrm{C}$

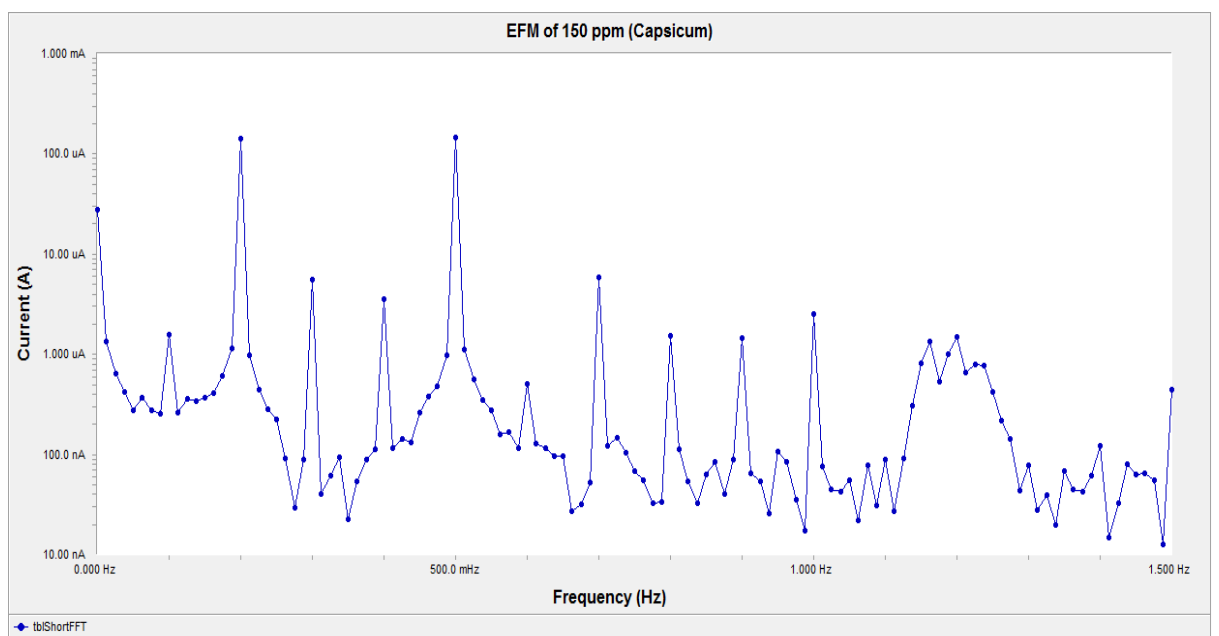

Figure 11 - EFM spectra for C-steel in $1 \mathrm{M} \mathrm{HCl}$ solutions in the presence of $150 \mathrm{ppm}$ Capsicum extract at $25^{\circ} \mathrm{C}$

The causality factors in Table 6 are very close to theoretical values $(2.0 \& 3.0)$ which according to EFM theory should guarantee the validity of Tafel slopes and corrosion current densities and indicate that the measured data are of good quality. The deviation of causality factors from their ideal values might be due to the perturbation amplitude was too small or the resolution of the frequency spectrum is not high enough also another possible explanation that the extract is not performing very well. The obtained results showed good agreement of inhibition efficiency obtained from the potentiodynamic polarization, EIS and weight loss methods. 
Table 6 - Electrochemical kinetic parameters obtained from EFM technique for $C$-steel in the absence and presence of various concentrations of Capsicum extract in $1 \mathrm{M} \mathrm{HCl}$ at $25^{\circ} \mathrm{C}$

\begin{tabular}{|c|c|c|c|c|c|c|c|c|c|}
\hline Comp. & $\begin{array}{c}\text { Conc., } \\
\text { ppm }\end{array}$ & $\begin{array}{c}\mathrm{i}_{\text {corr }} \\
\mu \mathrm{Acm}^{-2}\end{array}$ & $\begin{array}{c}\beta_{\mathrm{c}} \\
\mathrm{mVdec}^{-1}\end{array}$ & $\begin{array}{c}\beta_{\mathrm{a}} \\
\mathrm{mVdec}^{-1}\end{array}$ & CF-2 & CF-3 & $\theta$ & $\%$ IE & $\begin{array}{l}\text { CR, } \\
\mathrm{mmy}^{-1}\end{array}$ \\
\hline Blank & 00 & 628.1 & 126 & 99 & 1.782 & 2.811 & ---- & ---- & 287.1 \\
\hline \multirow{6}{*}{ 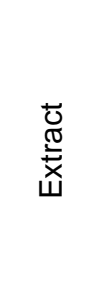 } & 50 & 255.5 & 185 & 140 & 1.643 & 2.641 & 0.593 & 59.3 & 116.8 \\
\hline & 100 & 244.7 & 160 & 127 & 1.821 & 2.501 & 0.611 & 61.1 & 111.8 \\
\hline & 150 & 238.4 & 135 & 102 & 1.511 & 2.716 & 0.621 & 62.1 & 108.7 \\
\hline & 200 & 200.5 & 127 & 114 & 1.881 & 2.820 & 0.682 & 68.2 & 102.3 \\
\hline & 250 & 186.1 & 138 & 124 & 1.943 & 2.900 & 0.704 & 70.4 & 91.6 \\
\hline & 300 & 101.5 & 144 & 126 & 1.660 & 2.898 & 0.838 & 83.8 & 84.6 \\
\hline
\end{tabular}

\subsection{Energy dispersion spectroscopy (EDX) studies}

The EDX spectra were used to determine the elements present on the surface of C-steel and after 3 days of exposure to the uninhibited and inhibited $1 \mathrm{M} \mathrm{HCl}$. Figure 12 shows the EDX analysis result on the composition of C-steel only without the acid and extract treatment. The EDX analysis indicates that only $\mathrm{Fe}$ and oxygen were detected, which shows that the passive film contained only $\mathrm{Fe}_{2} \mathrm{O}_{3}$. Figure 12 portrays the EDX analysis of $\mathrm{C}$-steel in $1 \mathrm{M} \mathrm{HCl}$ only and in the presence of 300 ppm of extract. The spectra show additional lines, demonstrating the existence of $C$ (owing to the carbon atoms of Capsicum extract). These data shows that the carbon and $\mathrm{N}$ materials covered the specimen surface. This layer is entirely owing to the extract, because the carbon and $\mathrm{N}$ signals are absent on the specimen surface exposed to uninhibited $\mathrm{HCl}$. It is seen that, in addition to $\mathrm{Mn}, \mathrm{O}, \mathrm{C}$. and $\mathrm{N}$ were present in the spectra. A comparable elemental distribution is shown in Table 7.

\section{carbon steel alone}

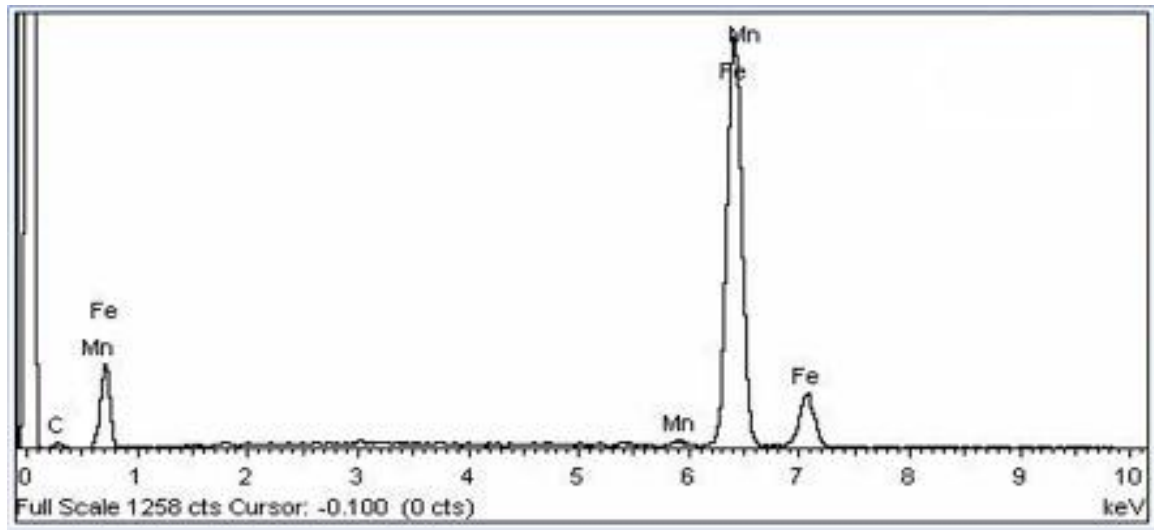

Blank

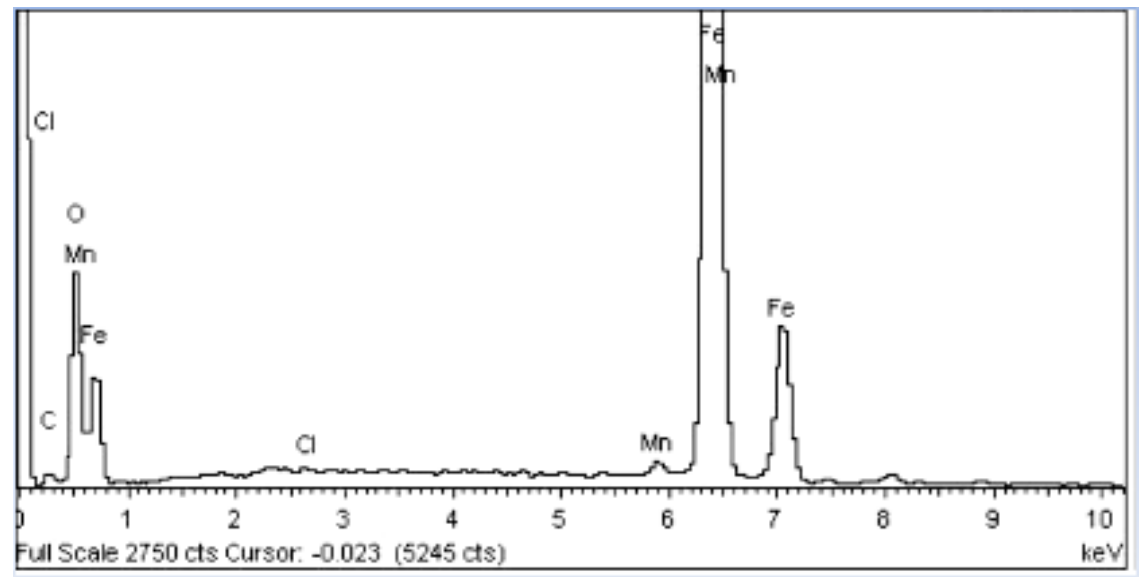




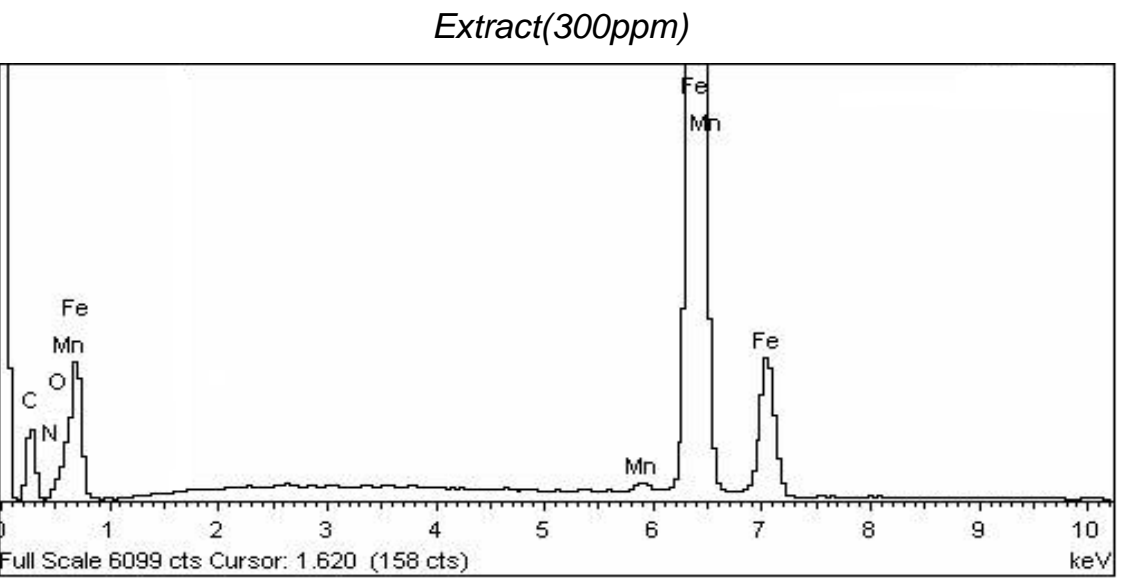

Figure 12 - EDX analysis on C-steel in presence and absence of 300ppm capsicum extract for 3 days immersion

Table 7 - Surface composition (weight \%) of C-steel alloy after 3days of immersion in $\mathrm{HCl}$ without and with 300ppm of capsicum extract

\begin{tabular}{||l|c|c|c|c|c|c||}
\hline \multicolumn{1}{|c|}{ (Mass \%) } & $\mathrm{Fe}$ & $\mathrm{Mn}$ & $\mathrm{C}$ & $\mathrm{O}$ & $\mathrm{N}$ & $\mathrm{cl}$ \\
\hline \hline carbon steel alone & 96.78 & 0.61 & 4.87 & ---- & --- & --- \\
\hline Blank & 55.83 & 0.31 & 2.12 & 39.24 & ---- & 0.32 \\
\hline Capsicum extract & 60.37 & 0.53 & 20.45 & 12.88 & 6.07 & --- \\
\hline
\end{tabular}

\subsection{Scanning electron microscopy (SEM) studies}

Figure (13) represents the micrograph obtained of $\mathrm{C}$-steel samples after exposure to $1 \mathrm{M} \mathrm{HCl}$ for three days immersion. It is clear that C-steel alloy surfaces suffer from severe corrosion attack. Figure 13 reveals the surface on $\mathrm{C}$-steel al loy after exposure to $1 \mathrm{M} \mathrm{HCl}$ solution containing $300 \mathrm{ppm}$ of capsicum extract. It is important to stress out that when the compound is present in the solution, the morphology of C-steel alloy surfaces are quite different from the previous one, and the specimen surfaces were smoother. We noted the formation of a film which is distributed in a random way on the whole surface of the C-steel alloy. This may be interpreted as due to the adsorption of capsicum extract on the C-steel alloy surface incorporating into the passive film in order to block the active site present on the C-steel alloy surfaces. Or due to the involvement of extract molecules in the interaction with the reaction sites of C-steel alloy surface, resulting in a decrease in the contact between C-steel alloy and the aggressive medium and sequentially exhibited excellent inhibition effect [31-32].

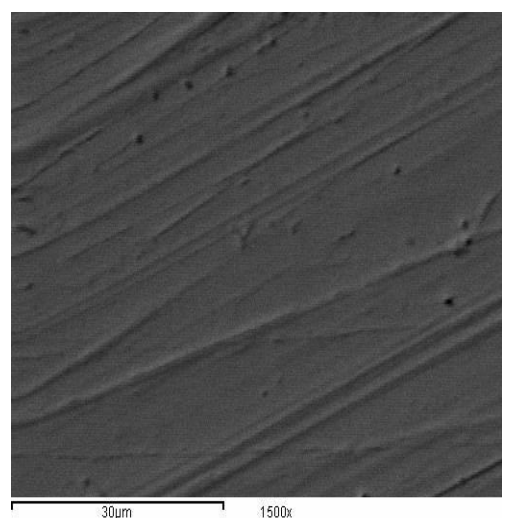

Pure sample

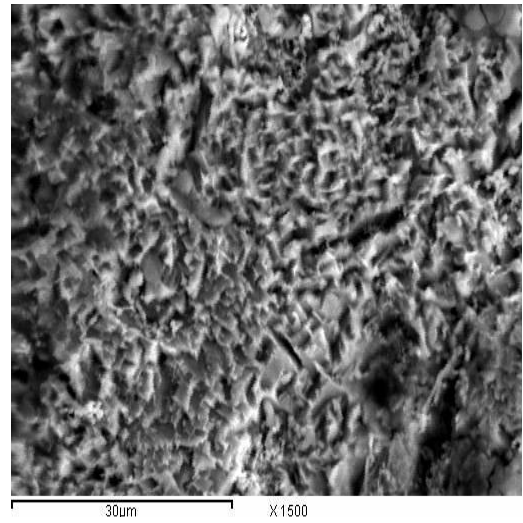

Blank

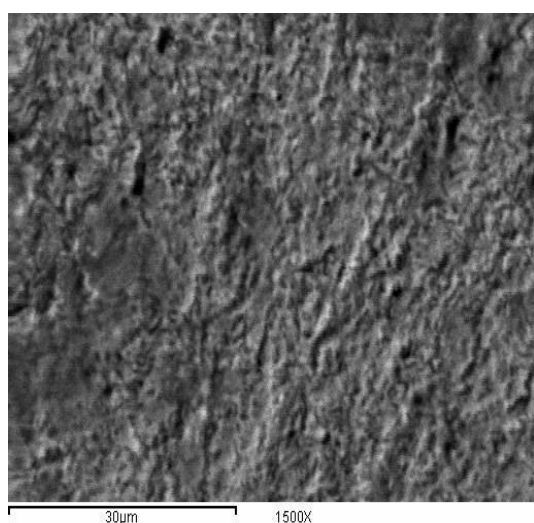

capsicum extract

Figure 13 - SEM micrographs for C-steel in absence and presence of 300 ppm of Capsicum extract 


\subsection{Mechanism of corrosion inhibition}

Corrosion of $\mathrm{C}$-steel in $\mathrm{HCl}$ was found inhibited in presence of extract. From analysis of the results obtained by various techniques it was recognized that changing surface property of steel with concentration of extract was responsible for retarded corrosion rate which corresponds to molecular adsorption of extract over C-steel surface. It is well known that most of the extracts fall under the category of adsorption type extracts and inhibit the corrosion by getting absorbed on the surface [29]. The organic species probably became protonated in acid solution which favored adsorption of these molecules over surface of negatively charged Csteel (electrostatic bonding) [30]. Adsorption of $\mathrm{Cl}$ over C-steel surface produced unbalanced negative charge which promoted adsorption of extract molecules at most active sites and inhibition efficiency was enhanced due to synergistic effect. Also these organic compounds contain $\mathrm{N}$, O heteroatoms, fused benzene rings and $\mathrm{OH}$ molecules in their chemical structures which contributed electrons for sharing with vacant $d$ orbit electrons of iron (chemisorption). On the basis of facts discussed above it can be said that corrosion inhibition greatly depends upon adsorption of extract molecules over surface of C-steel. In our case adsorbed extract molecules accumulated at the metal/acid interface and constructed a layer surrounding Csteel. This layer prevented C-steel from further being corroded.

\section{CONCLUSIONS}

Based on the above results, the following conclusions can be drawn:

- Aqueous extract of Capsicum extract was found to be an efficient, eco-friendly and low cost extract for the corrosion of $\mathrm{C}$-steel in $1 \mathrm{M}$ $\mathrm{HCl}$

- Inhibition efficiency increased with an increase in Capsicum extract content in $1 \mathrm{M} \mathrm{HCl}$ but decreased with rise in temperature

- The corrosion process is inhibited by adsorption of the Capsicum extract on the C-steel surface following the Langmuir adsorption isotherm. This indicates that the inhibition effect of the extract is due to adsorption of some or all the listed phytochemical constituents

- The negative free energy $\left(-\Delta G^{\circ}\right.$ ads $)$ of adsorption indicates strong and spontaneous adsorption of the Capsicum extract on the C-steel surface

- Values of Tafel constants $\beta_{a}$ and $\beta_{c}$ confirm that the Capsicum extract acts like mixed type inhibitor

- Increase in $\mathrm{R}_{\mathrm{ct}}$ values and decrease in $\mathrm{i}_{\text {corr }}$ and $\mathrm{C}_{\mathrm{dl}}$ values confirm that the Capsicum extract is adsorbed on the C-steel surface and inhibition process is followed by monolayer adsorption

- The inhibition efficiencies determined by chemical and electrochemical methods are in reasonable good agreement

- Thus the Capsicum extract was proved to be an effective.

\section{REFERENCES}

[1] A.Y.El-Etre (2007) Inhibition of acid corrosion of carbon steel using aqueous extract of olive, Leaves, J. Coll. Interf. Sci., 314, 578-583.

[2] A.Y.El-Etre (2006) Investigation of the Potential of Some plant extracts to inhibit the corrosion of duplex stainless steels in acidic media, Appl. Surf. Sci., 252, 8521-8525.

[3] M.Benabdellah, M.Benkaddour, B.Hammouti, M. Bendahhou, A.Aouniti (2006) Inhibition of steel corrosion in $2 \mathrm{M} \mathrm{H}_{3} \mathrm{PO}_{4}$ by artemisia oil, Appl. Surf. Sci. 252, 6212- 6217.

[4] E.Chaieb, A.Bouyanzer, B.Hammouti, M. Benkaddour (2005) Inhibition of the corrosion of steel in $1 \mathrm{M} \mathrm{HCl}$ by eugenol derivatives, Appl. Surf. Sci., 246, 199-206.

[5] B.Müller, W.Kläger (1996) The effect of $\mathrm{pH}$ on the corrosion inhibition of zinc pigments by phenol derivatives, Corros. Sci., 38, $1869-1875$.

[6] Y.Li, P.Zhao, Q.Liang, B.Hou (2005) Berberine as a nature source inhibitor for mild steel in $1 \mathrm{M} \mathrm{H}_{2} \mathrm{SO}_{4}$, Appl. Surf. Sci., 252, 1245-1253.

[7] A.Y.El-Etre, M.Abdallah, Z.E.El-Tantawy (2005) Corrosion inhibition of some metals using lawsonia extract, Corros.Sci., 47, 385-395.

[8] A.Bouyanzer, B.Hammouti, L.Majidi (2006) Pennyroyal oil from Mentha pulegium as corrosion inhibitor for steel in $1 \mathrm{M} \mathrm{HCl}$, Mater. Lett, 60, 28402843.

[9] A.Y.El-Etre (2003) Inhibition of aluminum corrosion using opuntia extract, Corros. Sci, 45, 2485-2495.

[10] S.Mondal, D.Das, D.Maiti, S.K.Roy, S.S.Islam (2009) Structural investigation of a heteropoly saccharide isolated from the green fruits of capsicum, Carbohyd. Res., 344, 1130-1135.

[11] A.Marin, F.Ferreres, F.A.T.Barberan, M.I.Gil (2004) Characterization and Quantitation of Antioxidant Constituents of Sweet Pepper (Capsicum annuum L.) J. Agric. Food Chem., 52, 3861-3869.

[12] P.M.Eggink, C.Maliepaard, Y.Tikunov, J.P.W. Haanstra , A.G.Bovy, R.Visser (2012) A taste of sweet pepper: Volatile and non-volatile chemical composition of fresh sweet pepper (Capsicum annuum) in relation to sensory evaluation of taste, Food Chem., 132, 301-310.

[13] J.D.Talati, R.Modi (1986) Inhibition of corrosion of aluminum -copper alloy in sodium hydroxide", Trans SEAST, 11, 259-271.

[14] S.S.Abdel-Rehim, K.Khaled, N.Abd-Elshafi (2006) Electrochemical frequency modulation as a new technique for monitoring corrosion inhibition of iron in acid media by new thiourea derivative, Electrochim. Acta, 51, 3269-3277. 
[15] R.Bosch, J.Hubrecht, W.F.Bogaerts, B.Syrett (2001) Electrochemical technique for online corrosion monitoring corrosion, Corrosion, 57, 60-70.

[16] N.Lahhit, A.Bouyanzer, J.Desjobert (2011) Fennel (Foeniculum vulgare) essential oil as green corrosion extract of stainless steel in hydrochloric acid solution, Port. Electrochim. Acta, 29, 127-138.

[17] F.Donahue, K.Nobe (1965) Theory of organic corrosion extracts: Adsorption and linear free energy relationships J. Electrochem. Soc., 112, 886-891.

[18] E.Kamis, F.Belluci, R.Latanision, E.S.El-Ashry (1991) Acid Corrosion Inhibition of Nickel by 2(Triphenosphoranylidene) Succinic Anhydride, Corrosion, 47, 677-686.

[19] X.Li, G.Mu (2005) Tween as corrosion extract for cold rolled steel in sulphuric acid: Weight loss study, electrochemical characterization and AFM, Appl.Surf.Sci, 252, 1254-1265.

[20] G.Mu, X.Li, G.Li (2005) Synergistic inhibition between tween 60 and $\mathrm{NaCl}$ on the corrosion of cold rolled steel in $0.5 \mathrm{M}$ sulfuric acid, Corros. Sci, 47, 1932-1952.

F.S.Souza, A.Spinelli (2009) Caffeic acid as a green corrosion extract for mild steel, Corros. Sci., 51, 642-649.

[21] M.I.Awad (2006) Eco friendly corrosion extracts: Inhibitive action of quinine for corrosion of low carbon steel in $1 \mathrm{M} \mathrm{HCl}$, J. Appl. Electrochem., 36, 1163-1168.

[22] P.Okafor, M.Ikpi, I.Uwah, E.Ebenso, U.Ekpe, S.Umoren (2008) Extracty action of Phyllanthus amarus extracts on the corrosion of mild steel in acidic media, Corros. Sci., 50, 310 -2317.

[23] A.Popova, E.Sokolova, S.Raicheva, M.Christov (2003) AC and DC study of the temperature effect on mild steel corrosion in acid media in the presence of benzimidazole derivatives, Corros. Sci., 45, 33-58.

[24] A.S.Fouda, A.Al-Sarawy, F.Ahmed, H.El-Abbasy (2009) Corrosion inhibition of aluminum 6063 using some pharmaceutical compounds, Corros. Sci., 51 . 485-492.

[25] E.Ferreira, C.Giancomrlli, F.Giancomrlli, A.Spinelli (2004) Evaluation of the extract effect of L-ascorbic acid on the corrosion of mild steel, Mater. Chem. Phys., 83, 129 -134.

[26] M.Quraishi, J.Rawad, M.Ajmal (1998) Macrocyclic Compounds as Corrosion Extracts, Corrosion, 54, 996-1002.

[27] J.Wanklyn (1981) The role of molybdenum in the crevice corrosion of stainless steels, Corros. Sci., 21, 211-225.

[28] M.G.Fontana (1986) Corrosion enginerring, Mcgraw hill, book, $3^{\text {rd }}$ edition.

[29] M.Lebrini, M.Lagrenee, M.Traisnel, L.Gengembre, H.Vezin, F.Bentiss (2007) Enhanced corrosion resistance of mild steel in normal sulfuric acid medium by 2,5-bis(n-thienyl)-1,3,4-thiadiazoles: Electrochemical, X-ray photoelectron spectroscopy and theoretical studies, Appl. Sur. Sci., 253, 92679276.

[30] S.Muralidharan, S.Phani, S.Pitchumani, S.Ravichandran, J.lyer (1995) Electrochemical Probing of Internal vs external species in microporous materials: application to zeolites, Electrochem. Soc., 142, 1478-1483.

[31] R.A.Prabhu, T.Venkatesha, A.Shanbhag, G.Kulkarni, R.Kalkhambkar (2008) Inhibition effects of some Schiff's bases on the corrosion of mild steel in hydrochloric acid solution, Corros.Sci., 50, 33563362.

\title{
IZVOD
}

\section{EKSTRAKT PAPRIKE KAO ZELENI INHIBITOR ZA KOROZIJU UGLJENIČNOG ČELIKA U RASTVORU HLOROVODONIČNE KISELINE}

\begin{abstract}
Ekstrakt paprike je potvrđen kao zeleni inhibitor za koroziju ugljenog čelika u rastvoru $1 \mathrm{M} \mathrm{HCl} i$ istraživan je preko gubitka težine, potenciodinamičke polarizacije, merenjem impedanse (EIS ), elektrohemijskog modula frekvencije (MKE), disperzne spektroskopije (EDS) i skenirajuće elektronske mikroskopije (SEM) kao metoda za praćenje korozije. Inhibitorna svojstva ekstrakta paprike se pripisuje prisustvu kapcinske i askorbinske kiseline kao glavnih sastojaka u ekstraktu. Merenja su pokazala da ovaj ekstrakt deluje kao mešoviti tip inhibitora. Efikasnost inhibicije je utvrđeno da se povećava sa povećanjem koncentracije ekstrakta. Rezultati dobijeni različitim tehnikama su blizu jedan drugom i maksimalnu efikasnost od $86 \%$ je potvrđena u koncentraciji ekstrakta od 300 ppm. Model Langmuirove izoterme je najpogodniji da bi se objasnilo adsorpcijsko ponašanje inhibitora na ugljeničnoj-čeličnoj površini. Molekularna adsorpcija ekstrakta preko ugljenične- čelične površine je proglašena krivim za inhibitorsku koroziju ugljeničnog- čelika u kiselini.
\end{abstract}

Ključne reči: Inhibitorska korozija, ekstrakt paprike, ugljenični čelik, $\mathrm{HCl}$.

\section{Naučni rad}

Rad primljen: 12. 09. 2015.

Rad prihvaćen: 26. 10. 2015.

Rad je dostupan na sajtu: www.idk.org.rs/casopis 